Article

\title{
Environmental and Economic Benefits from the Phase-out of Residential Oil Heating: A Study from the Aosta Valley Region (Italy)
}

\author{
Alessandro Casasso $^{1, *(\mathbb{D})}$, Pietro Capodaglio ${ }^{2}$, Fulvio Simonetto ${ }^{2}$ and Rajandrea Sethi $^{1}$ \\ 1 Department of Environmental, Land and Infrastructure Engineering (DIATI), Politecnico di \\ Torino, corso Duca degli Abruzzi 24, 10129 Torino, Italy \\ 2 ARPA Valle d'Aosta, località La Maladière 48, 11020 Saint-Christophe (Aosta), Italy \\ * Correspondence: alessandro.casasso@polito.it; Tel.: +39-320-421-3886
}

Received: 1 June 2019; Accepted: 26 June 2019; Published: 2 July 2019

check for updates

\begin{abstract}
Although its use is declining, oil heating is still used in areas not covered by the methane grid. Oil heating is becoming more and more expensive, requires frequent tank refill operations, and has high emissions of greenhouse gas (GHG) and air pollutants such as SOx. In addition, spills from oil underground storage tanks (USTs) represent a serious environmental threat to soil and groundwater quality. In this paper, we present a comprehensive analysis on technical alternatives to oil heating with reference to the Aosta Valley (NW Italy), where this fuel is still often used and numerous UST spills have been reported in the last 20 years. We assess operational issues, GHG and pollutant emissions, and unit costs of the heat produced for several techniques: LPG boilers, wood boilers (logs, chips, pellets) and heat pumps (air-source, geothermal closed-loop and open-loop systems). We examine the investment to implement such solutions in two typical cases, a detached house and a block of flats, deriving payback times of about 3-8 years. Wood log boilers turn out to be the most economically convenient solutions; however, heat pumps provide several benefits from the operational and environmental points of view. In addition, including solar thermal panels for domestic hot water or a photovoltaic plant would have payback times of about 6-9 years. The results highlight the economic feasibility and the multiple benefits of a rapid phase-out of oil heating in Italy.
\end{abstract}

Keywords: oil heating; underground storage tank; contamination; greenhouse gas; air pollution; NOx; SOx; particulate matter; renewable heating

\section{Introduction}

Oil still covers about $10 \%$ of the heating demand in the world [1] and $12 \%$ in the European Union [2], yet its use is declining due to the increased fuel cost (e.g., it has more than tripled in the USA since 2000 [3]) and the high emissions of pollutants and greenhouse gases. The frequent occurrence of leakage episodes from underground storage tanks (USTs) is another major concern due to the consequent expense for tank removal, environmental investigations and possible remediation of soil and groundwater. Interest on this topic was first raised in the Eighties in the USA, as the US Environmental Protection Agency (USEPA) developed a specific program which identified more than 3.5 million USTs [4]. Since then, more than 500,000 leakage episodes have been observed according to different sources [5-7]. As for causes, Ram et al. [5] found that $74 \%$ of fuel releases occur in the tank and/or the pipes, where structural failure $(46 \%)$, corrosion $(27 \%)$, and loose fittings $(12 \%)$ are the most common causes, while the rest is due to incorrect filling operations. The remediation costs for leaking underground storage tanks (LUST) are very large relatively to the small ground volume involved, ranging between $142 \mathrm{k} \$$ and $329 \mathrm{k} \$$ per each site in the USA $[5,6]$. 
Recently, the GRETA project [8] addressed the issue of LUST in Aosta Valley (NW Italy) [9], a small mountainous Italian region ( $3261 \mathrm{~km}^{2}, 128,230$ inhabitants) where, as shown later, oil heating is still quite used. Available data on soil and groundwater remediation procedures highlight that 68 suspect or actual leakage episodes occurred between 1999 and 2018, which involved heating fuel tanks, gas stations and other kinds of hydrocarbon storage, as reported in Table 1. Ten of these 68 sites have been remediated with a median cost of $114 \mathrm{k} €$ which is consistent with data from the USA $[5,6]$.

Table 1. Data on remediation procedures on underground storage tanks (USTs) in Aosta Valley [9].

\begin{tabular}{ccc}
\hline Classification & Category & Value \\
\hline \multirow{2}{*}{ UST type } & Heating oil tanks & 25 tanks \\
& Gas stations & 32 tanks \\
& Fuel storage & 10 tanks \\
& Other/Unknown & 1 tank \\
\hline \multirow{2}{*}{ Remediation } & Remediated sites & 10 sites \\
& Median remediation cost & $114,159 €$ \\
\hline
\end{tabular}

Data highlight that a large share of leaking episodes occurred in gas stations, where possible failures in USTs are more likely to be detected due to the strict monitoring of fillings and sales and to the periodic controls on the structural integrity of the tanks. On the other hand, relatively a few procedures involve heating fuel tanks, which represent almost all USTs but are not subjected to any compulsory monitoring: for these tanks, leaking occurrence has, therefore, generally been revealed by odors or iridescent spots on surficial waters. Regional guidelines have been recently published in the Aosta Valley region aimed at gas stations USTs but containing good practices applicable also to the periodic monitoring of heating oil tanks [10].

The phase-out of residential oil heating has been addressed in a few studies so far. Hast et al. [11] found that replacing oil heating in Finland is economically convenient at the end of the operational lifetime of the boiler, while an early replacement strongly depends on the oil price. Most studies agree that the operational costs are the main driver for the choice of alternative heating techniques [11,12], although residential users are more likely to consider other factors such as comfort and reliability [13]. As for environmental impacts of oil heating, Kheirbek et al. [14] state that phasing it out in New York State and City would avoid 290 premature deaths per year thanks to the reduction of PM 2.5 concentrations. However, the replacing technique should also be considered: for example, shifting $20 \%$ of heating systems from oil with wood burning in Thessaloniki resulted in a $+52 \%$ increase of PM 2.5, which is deemed responsible for about 200 premature deaths per year [15].

These studies provide a knowledge base for the work presented in this paper, which comprehensively addresses the issue of replacement of oil boilers, with an application to the case study area of Aosta Valley. The practical issues of replacement heating techniques, such as fuel storage, civil engineering works, terminals, and operation are examined to identify potential operating contexts. The environmental impact of heating and domestic hot water (DHW) production is then evaluated through an analysis of greenhouse gas and air pollutant emission factors. Operational costs are estimated based on a research on the Italian market, and trends are identified when available. The return on investment of replacing oil heating is analyzed with reference to two benchmark case studies, i.e., a detached house and a block of flats. The economic results are integrated with an analysis of environmental externalities (greenhouse gases and pollutant emissions) and then discussed, comparing strengths and weaknesses of each heating and DHW production technique and deriving policy recommendation to phase out oil heating.

\section{Technical Analysis of Replacement Options for Oil Heating}

Aosta Valley is a mountainous region with an average elevation of about $2100 \mathrm{~m}$ a.s.l. and a semi-continental, temperate to cold climate [16]. Rainfall ranges from about $600 \mathrm{~mm} / \mathrm{year}$ in the bottom 
valley to $1800 \mathrm{~mm} /$ year on the highest peaks, with a regional average of $950 \mathrm{~mm} /$ year and a clear correlation with altitude [16]. Heating degree-days according to the Eurostat method [17] range from 2400-2800 HDD in the bottom valley from Pont-Saint-Martin to Aosta, where most of the population lives, to more than 5000 HDD in the highest settlements such as Valtournenche [18] (Figure 1). These climatic factors explain why Aosta Valley is the Italian region with the highest heating expense per family in Italy [19]. Getting into the detail of the energy sources used for heating, it turns out that oil is a residual option which is adopted in the case gas is not available [2,20]. Indeed, gas in Italy is much cheaper than oil since taxation on heating oil was raised in the mid-eighties [20]. Data on the diffusion of gas grids highlight that 50 of 74 municipalities of Aosta Valley do not have any methane grid [21], with a total population of about 27384 inhabitants (i.e., $21.4 \%$ of the population of Aosta Valley); the other 24 municipalities, mostly in the bottom valley from Pont-Saint-Martin to Saint-Pierre (Figure 1), are partially covered by the methane pipelines and a lower usage of oil boilers which is limited to the areas not covered by the methane grid.

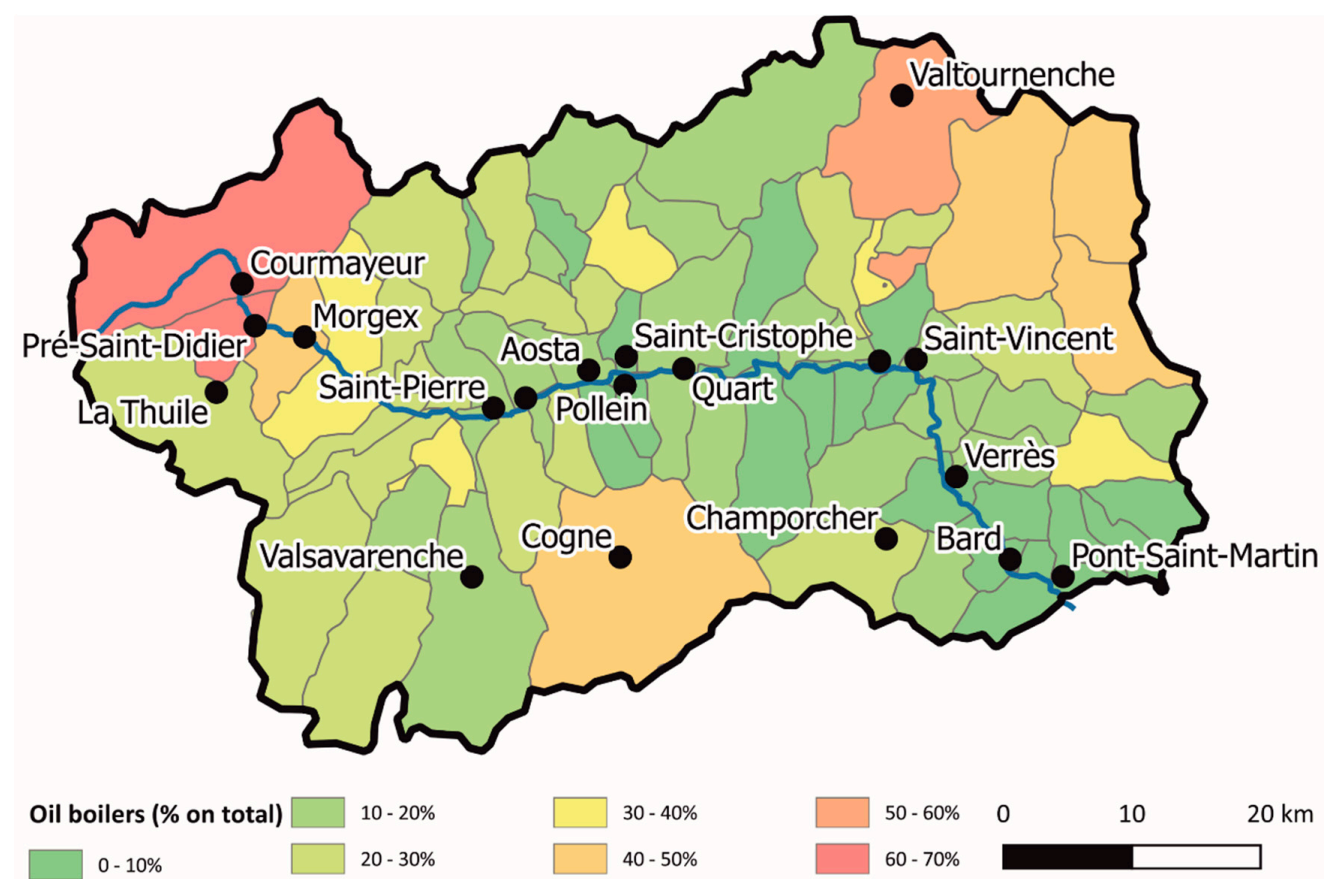

Figure 1. Map of Aosta Valley reporting the share of oil boilers on the total, based on the regional cadaster [22].

Therefore, the solutions considered in view of the phase-out of oil heating are the following: LPG boilers, wood-fueled (logs, chips, and pellets) boilers, and different kinds of heat pumps i.e., air-source (ASHP), ground-coupled heat pumps (GCHP), and groundwater heat pumps (GWHP).

The LPG boiler is the most similar technical solution to oil heating, since it provides unattended boiler operation with a single (or a few) tank refilling for each heating season, avoiding the more frequent maintenance operations required by wood-fueled boilers. In the case of leakage from LPG storage tanks (both above and underground) the fuel does not penetrate the ground and groundwater, and this prevents the contamination of the underground. On the other hand, LPG has the same GHG emissions of oil (as shown later in Section 3) and it is the most expensive heating fuel. A new tank (above or underground) must also be installed to switch from oil to LPG.

Wood-fueled heating has become very popular in recent years in Italy, and in Aosta Valley it is used by almost half of the population according to national statistics [19]. Three main kinds of wood fuel are available on the market: logs, chips, and pellets. Wood logs have the main advantage of possible self-production, which dramatically reduces their cost, but the hand loading of wood makes them unpractical for large size plants, e.g., for a block of flats. Wood chips are very cheap, they can be 
produced too, optimally exploiting forestry residues. The automatic loading makes them practical also for large-size systems such as district heating. Yet wood chips require large storage spaces, which could make them unpractical for residential application: about $1 \mathrm{~m}^{3}$ of storage volume is required for $1 \mathrm{MWh}$ of heat, i.e., 10 times the value heating oil. Wood pellets and logs are much denser, requiring respectively $0.35 \mathrm{~m}^{3}$ and $0.45 \mathrm{~m}^{3}$ of storage volume per MWh.

Wood pellet boilers combine the advantages of the automatic loading and the relatively small storage spaces required. They are generally sold in small bags of $15 \mathrm{~kg}$, thus limiting dust and sawdust in the storage room. These practical advantages, combined with an affordable price, have contributed to the large diffusion of this fuel in the 2000's, particularly in Italy which has become the second consumer (and the first importer) in the world [23].

Both LPG and wood biomass boilers can be adapted to any kind of hydronic and aeraulic heating terminal, with no interventions nor replacement required, which is the main technical drawback of heat pumps. Indeed, the efficiency of heat pumps strongly depends on the operating temperature of the heating terminals. Radiant panels are the most suitable terminals, and fan coils provide a good performance too, while heat pumps are hardly suitable for high-temperature radiators, which are still the most used heating terminals. However, radiator over-sizing, building retrofitting and heat pump control could greatly improve heat pump efficiency $[24,25]$.

Air-source heat pumps are the most widespread, covering $80 \%$ of the European heat pump market [26], due to the lower cost of installation compared to the geothermal ones. In addition, the need for space to install ground heat exchangers or wells for geothermal heat pumps could switch the choice to air-source ones, e.g., in the case of an autonomous installation in a block of flats. The main drawbacks of air-source heat pumps are the noise $[27,28]$, the reduction of thermal power delivered at low air temperatures and, in the presence of moist air, frosting [29,30]. Geothermal heat pumps use ground (ground-coupled, GCHP) or groundwater (GWHP) as a heat source or sink [31,32]. The need for borehole heat exchangers (BHEs) or wells increases the installation costs, but geothermal heat pumps are far more efficient than air-source ones [33]. Ground-coupled heat pumps (GCHPs), also known as closed-loop geothermal heat pumps, exchange heat with the ground through a closed pipe loop buried in the ground, usually in vertical boreholes drilled on purpose and called borehole heat exchangers (BHEs). Groundwater Heat Pumps (GWHPs), also known as open-loop geothermal heat pumps, exchange heat directly with groundwater abstracted by one or more wells; after the heat exchange takes place, water usually gets disposed into the same aquifer. This practice is allowed by the Italian law [34] but not in the Aosta Valley region, and this represents a major barrier to the diffusion of open-loop geothermal systems in a territory which would have a great potential for this technique [35,36].

The use of air-source heat pumps (ASHPs) dedicated to the production of DHW has grown recently due to their relatively low cost and high efficiency [26]. The DHW heat pump could be a viable solution for both wood-fueled boilers, allowing to have them switched off out of the heating season, and for all kinds of centralized space heating systems, for the separate production of DHW.

\section{GHG and Pollutant Emission Factors of Different Heating Techniques}

Aside from the prevention of soil and groundwater pollution, the replacement of oil heating systems reduces greenhouse gases (GHG) and air pollutant emissions. Table 2 reports a comparison of $\mathrm{CO}_{2}$ and pollutants emission factors related to different kinds of boilers, derived from the LCA database GEMIS 4.95-Global Emissions Model for integrated Systems [37]. GEMIS considers biomasses as carbon neutral $\left(0 \mathrm{gCO}_{2} / \mathrm{kWh}_{\text {th }}\right)$, although this assumption is not shared in related literature; for this reason, we considered other sources $[38,39]$ to derive $\mathrm{CO}_{2}$ emission factors for wood logs, chips, and pellets.

The comparison among fuels highlights that oil and LPG are the most carbon-intensive fuels, followed by methane $(-12.7 \%)$, which is reported in Table 2 as a term of comparison but is not considered as a replacement option for oil: indeed, methane in Italy is much cheaper than oil for 
heating $(-41 \%)$, and it requires a minimal investment for the replacement of the boiler. For this reason, as shown above, a negligible number of oil boilers is present in areas covered by the methane grid.

Table 2. GHG emission factors for different boilers. Data sources are GEMIS 4.95 [37], except for data related to wood biomass $\mathrm{CO}_{2}$ emissions, drawn from other sources [38,39].

\begin{tabular}{|c|c|c|c|c|}
\hline Technology & $\mathrm{CO}_{2}(\mathrm{~g} / \mathrm{kWh})$ & $\mathrm{CH}_{4}(\mathrm{mg} / \mathrm{kWh})$ & $\mathrm{N}_{2} \mathrm{O}(\mathrm{mg} / \mathrm{kWh})$ & $\mathrm{CO}_{2}$ eq. (g/kWh) \\
\hline Oil boiler & 267.837 & 10.850 & 7.233 & 270.658 \\
\hline Gas boiler & 233.582 & 10.669 & 4.268 & 235.605 \\
\hline LPG boiler & 269.995 & 21.326 & 4.265 & 272.912 \\
\hline Wood logs boiler & 6.000 & 488.801 & 7.966 & 49.162 \\
\hline Wood chips boiler & 19.000 & 129.406 & 5.176 & 31.237 \\
\hline Wood pellets boiler & 22.000 & 12.430 & 4.972 & 24.357 \\
\hline
\end{tabular}

The $\mathrm{CO}_{2}$ emission factors of fossil fuels provided by different sources vary in small ranges, since such emissions are almost exclusively due to their combustion. On the other hand, the carbon footprint of wood and derivates depends on transport distances and on the energy used for the transformation operations of wood (sawing, chipping, and pellettization), while $\mathrm{CO}_{2}$ emissions of wood combustion are considered as perfectly compensated by those removed by trees during their life cycle. Regarding pellet and wood chips, we have considered the values provided by Sjølie and Solberg [39] who analyzed the production of pellets with Canadian wood exported in Norway. They derive an emission factor between 113 and $482 \mathrm{kgCO}_{2} /$ ton of pellets, equal to $22-93 \mathrm{gCO}_{2} / \mathrm{kWh}_{\text {th }}$ assuming a typical Lower Heating Value (LHV) of $5.2 \mathrm{kWh} / \mathrm{kg}$ of pellets. The lowest value $\left(22 \mathrm{gCO}_{2} / \mathrm{kWh}_{\mathrm{th}}\right)$, based on an on-site production in Norway and truck transportation to Germany (from Averøy to Hamburg, about $1300 \mathrm{~km}$ ), could be considered as representative of the Italian situation, where $81 \%$ of pellets are imported, mostly from Austria (28\%) and other EU countries (40\%) within $1500 \mathrm{~km}$ distance from Aosta Valley [40]. The $\mathrm{CO}_{2}$ footprint of wood chips could be estimated to $100 \mathrm{kgCO}_{2} /$ ton of pellets (i.e., $19 \mathrm{gCO}_{2} / \mathrm{kWh}_{\text {th }}$ ) by removing the contribution of the transformation of wood chips into pellets $\left(13 \mathrm{kgCO}_{2} /\right.$ tons pellets). As a simplifying assumption, we assume that the mass reduction in the transformation from moist chips to pellets is perfectly compensated by the increase of LHV. Regarding wood logs, Klein et al. [38] found $\mathrm{CO}_{2}$ emission factors for different wood types in Bavaria (Germany) ranging between 9 and $15 \mathrm{kgCO}_{2} / \mathrm{m}^{3}$ of dry wood, i.e., about $2-6 \mathrm{gCO}_{2} / \mathrm{kWh}_{\mathrm{th}}$. For this study, we adopted the highest value $\left(6 \mathrm{gCO}_{2} / \mathrm{kWh}_{\text {th }}\right)$ considering a short supply chain with a negligible transport contribution to $\mathrm{CO}_{2}$ emissions. The values of $\mathrm{CO}_{2}$ emission factors assigned to wood-fueled boilers are in the orders of magnitude provided by other literature sources [41,42] and, unless we consider very long supply chains (e.g., American or Asian raw wood), the abatement of $\mathrm{CO}_{2}$ emissions exceeds $80 \%$ with respect to methane, LPG, and oil.

Methane and nitrous oxide emissions were also considered to assess the total GHG effect as $\mathrm{CO}_{2}$ equivalent. The 20-years GWP values provided by the AP5 report of the International Panel on Climate Change [43], i.e., 84 for methane $\left(\mathrm{CH}_{4}\right)$ and 264 for nitrous oxide $\left(\mathrm{N}_{2} \mathrm{O}\right)$. As show in Table 2, emissions from fossil fuels and wood pellets are slightly increased, while a noticeable increase occurs for wood logs and chips due to the higher emissions of methane.

Other environmental factors should, however, be considered in the evaluation of different fuels. Wood biomasses are responsible for high emissions of air pollutants such as $\mathrm{SO}_{2}$ (with emissions similar to those of oil boilers), $\mathrm{NO}_{\mathrm{x}}, \mathrm{CO}, \mathrm{VOC}$ etc. The highest concern is raised by particulate matters, and numerous studies highlighted the impact of wood burning on air quality and their adverse impact on health. In the Po Plain, the contribution of wood burning to high air concentrations of PM10 and PM2.5 is in the order of 50\% during winter time [44-46]. However, large differences in pollutant emissions are observed among different wood fuels: wood logs produce $\mathrm{CO}$ emissions of about 30-100 times higher compared to both fossil fuels and chips/pellets (Table 3), as they are generally characterized by a poor combustion (e.g., wrong regulation of excess air); a similar difference between wood and fossil fuels is observed for VOC emissions. 
Table 3. Air pollutant emission factors for different boilers (Source: GEMIS 4.95 [37]).

\begin{tabular}{cccccc}
\hline Technology & $\left.\mathbf{S O}_{\mathbf{2}} \mathbf{( m g} / \mathbf{k W h}\right)$ & $\left.\mathbf{N O}_{\mathbf{x}} \mathbf{( m g} / \mathbf{k W h}\right)$ & $\mathbf{P M 1 0} \mathbf{( m g} / \mathbf{k W h})$ & $\mathbf{C O} \mathbf{( m g} / \mathbf{k W h})$ & $\mathbf{N M V O C}(\mathbf{m g} / \mathbf{k W h})$ \\
\hline Oil boiler & 168.723 & 154.994 & 3.617 & 51.665 & 10.850 \\
Gas boiler & 1.812 & 237.090 & 0.593 & 118.545 & 10.669 \\
LPG boiler & 0.000 & 94.781 & 0.592 & 169.421 & 21.326 \\
Wood logs boiler & 183.903 & 271.556 & 276.135 & 14120.900 & 1126.900 \\
Wood chips boiler & 109.177 & 388.218 & 50.966 & 388.218 & 129.406 \\
Wood pellets boiler & 131.935 & 298.325 & 70.797 & 248.604 & 55.245 \\
\hline
\end{tabular}

A further factor to be considered when evaluating wood biomass boilers is the time variation of pollutant emissions. A number of experimental studies agree that cold starts are critical for pollutant emissions [47-49], and hence, an accurate sizing of the heat storage tank could reduce the incidence of such conditions, with noticeable gains in energy efficiency and air quality impact [50]. This fact supports the advisability of using a separate DHW generator to avoid powering boilers for short cycles and out of the heating season. For this reason, a heat pump dedicated to the DHW production was included in all the technical solutions proposed in the economic feasibility analysis of Section 4.

The replacement of fossil fuels with wood biomasses has a few criticalities such as feedstock availability, supply chain and air quality impact. In addition, the relatively low value of volumetric LHV, and hence, the need for large storage spaces, could be an issue for their implementation in urban areas. For this reason, heat pumps rather than wood-fueled boilers should be regarded as the real mass-scale implementable technology to increase the share of renewable heat sources and, since they have no pollutant emissions on site, they are particularly suitable for air pollution offset purposes in urban areas.

The emission factors with heat pumps are reported in Table 4 (greenhouse gases) and Table 5 (air pollutants) and have been calculated with the following formula:

$$
\mathrm{EF}_{\mathrm{HP}}=\mathrm{EF}_{\mathrm{el}} / \mathrm{SPF}
$$

where $E F_{e l}$ is the GHG/pollutant emission factor of the Italian grid reported in Ref. [51] and SPF is the seasonal performance factor of the heat pump type considered, i.e., ground-coupled heat pump $(\mathrm{GCHP}, \mathrm{SPF}=4)$, groundwater heat pump (GWHP, SPF = 4.8), and air-source heat pump for heating (Heating ASHP, SPF = 2.5) and for DHW production (DHW ASHP, SPF = 2.8). The SPF of the air-source heat pump for DHW production has been set slightly higher than for heating: indeed, although the condensation temperature for DHW is higher (DHW is stored at $55^{\circ} \mathrm{C}$, compared to low-temperature radiators which operate at $40-45^{\circ} \mathrm{C}$ ), this kind of heat pump also operates out of the Winter season, when the higher outdoor temperature allows higher SPF values to be achieved. Since heating ASHPs also include the DHW production, the electric consumption to cover the DHW demand was calculated considering the related SPF value (i.e., $\mathrm{SPF}=2.8$ instead of SPF $=2.5$ of the heat pump in heating mode). For the other heat pump types (ground-coupled and groundwater), the SPF values were kept the same for heating and for DHW since the heat source temperature is much less variable than the air.

Table 4. GHG emission factors of electricity from the Italian grid in 2016 [51] and for different kinds of heat pumps powered with electricity from the Italian grid.

\begin{tabular}{ccccc}
\hline Technology & $\mathbf{C O}_{\mathbf{2}}(\mathbf{g} / \mathbf{k W h})$ & $\left.\mathbf{C H}_{\mathbf{4}} \mathbf{( m g} / \mathbf{k W h}\right)$ & $\mathbf{N}_{\mathbf{2}} \mathbf{O}(\mathbf{m g} / \mathbf{k W h})$ & $\left.\mathbf{C O}_{\mathbf{2}} \mathbf{~ e q} \cdot \mathbf{( g} / \mathbf{k W h}\right)$ \\
\hline Electricity & 303.472 & 0.643 & 1.519 & 303.927 \\
Heating ASHP (SPF $=2.5)$ & 121.389 & 0.257 & 0.607 & 121.571 \\
GCHP (SPF = 4) & 75.868 & 0.161 & 0.380 & 75.982 \\
GWHP (SPF = 4.8) & 63.223 & 0.134 & 0.316 & 63.318 \\
DHW ASHP (SPF = 2.8) & 108.383 & 0.230 & 0.542 & 108.545 \\
\hline
\end{tabular}


Table 5. Air pollutant emission factors of electricity from the Italian grid in 2016 [51] and for different kinds of heat pumps powered with electricity from the Italian grid.

\begin{tabular}{cccccc}
\hline Technology & $\begin{array}{c}\mathbf{S O}_{\mathbf{2}} \\
(\mathbf{m g} / \mathbf{k W h})\end{array}$ & $\begin{array}{c}\mathbf{N O}_{\mathbf{x}} \\
\mathbf{( m g / k W h )}\end{array}$ & $\begin{array}{c}\mathbf{P M 1 0} \\
(\mathbf{m g} / \mathbf{k W h})\end{array}$ & $\begin{array}{c}\mathbf{C O} \\
\mathbf{( m g / k W h})\end{array}$ & $\begin{array}{c}\text { NMVOC } \\
(\mathbf{m g} / \mathbf{k W h})\end{array}$ \\
\hline Electricity & 71.589 & 237.566 & 5.701 & 95.725 & 82.653 \\
Heating ASHP (SPF = 2.5) & 28.636 & 95.027 & 2.280 & 38.290 & 33.061 \\
GCHP (SPF = 4) & 17.897 & 59.392 & 1.425 & 23.931 & 20.663 \\
GWHP (SPF = 4.8) & 14.914 & 49.493 & 1.188 & 19.943 & 17.219 \\
DHW ASHP (SPF = 2.8) & 25.568 & 84.845 & 2.036 & 34.188 & 29.519 \\
\hline
\end{tabular}

GHG emissions of heat pumps are not only due to the electricity used to feed them, but also to other factors among which refrigerant leaks are the most relevant, i.e., 10\% of GHG emissions in a GCHP if R-134a (GWP = 1430) is used [52]. However, as the global warming power of heat pumps is going to be dramatically reduced in the future with the F-gas EU directive [53], the contribution of refrigerant losses to GHG emissions will move from marginal to negligible and it was therefore neglected in this study.

The reduction of $\mathrm{CO}_{2}$ by using heat pumps ranges from $54 \%$ to $76 \%$ compared to oil boilers, depending on the heat source (air, ground, ground water). These results are consistent with other studies on heat pumps with reference to the Italian electrical grid [52,54,55]. Other GHG like methane and nitrous oxide are abated by more than $90 \%$. In addition, the GHG emission factor of electricity has declined of 32\% between 2005 and 2016 [51] (Figure 2), thanks to the progressive phase out of liquid and solid fossil fuels in its production process, and a further reduction of GHG emissions is expected in the future, since the Italian government recently pledged to completely phase out coal as a source of energy by 2025 [56]. When compared to fossil fuels, GHG reductions achievable by using heat pumps systems are therefore likely to increase in the foreseeable future.

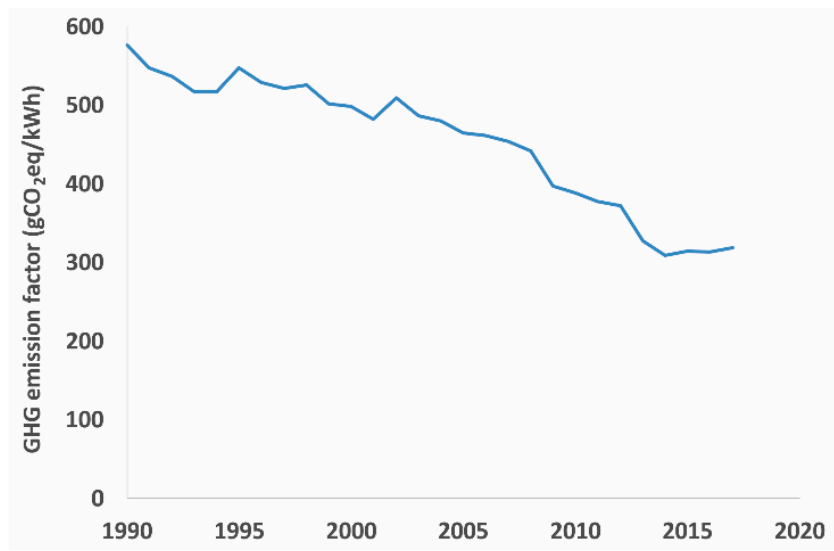

Figure 2. Greenhouse Gas (GHG) emission factor of electricity produced in Italy [51].

Compared to oil boilers, heat pumps also show reduced global emissions of SOx $(83 \div 91 \%)$, NOx $(38 \div 68 \%)$, PM10 $(37 \div 67 \%)$ and CO $(26 \div 61 \%)$, while they increased non-methane volatile organic compounds (NMVOC) emissions $(58 \div 205 \%$ ), due to the contribution of waste combustion in the electricity mix. NMVOC emissions due to heat pump systems are, however, much lower than those caused by biomass boilers and in the order of those of LPG boilers (-19\% to $55 \%)$.

\section{Economic Feasibility}

The economic benefit of replacing oil heating systems is not limited to the avoidance of groundwater contamination risks and the associated high remediation costs. As heating oil is an expensive fuel, replacing it can lead to noticeable reductions in heat production costs (Section 4.1). However, an investment is needed, which should be recovered in a reasonable amount of time. Two typical 
cases are therefore presented in Section 4.2: a detached house and a block of 50 flats. The payback time is estimated in Section 4.3. Finally, solar thermal panels (Section 4.4) and a photovoltaic system (Section 4.5) are examined separately as additional interventions.

\subsection{Estimation of Heat Unit Costs}

The unit cost of heating with a boiler using a certain fuel could be calculated as:

$$
\text { Heating cost }=\frac{U P_{\text {fuel }}}{L H V \cdot \eta_{g}}
$$

where $U P_{\text {fuel }}$ is the unit price of the fuel, the $L H V$ is the lower heating value of the fuel, and $\eta_{g}$ is the heat generation efficiency of the boiler. The units adopted for UP and LHV should be consistent, e.g., both expressed per unit volume or per unit mass.

Table 6 shows unit heating costs estimated with a market survey: LPG is the most expensive $(+39 \%)$, while wood logs $(-74 \%)$, chips $(-84 \%)$ and pellets $(-62 \%)$.

Table 6. Heating unit costs of different fuels calculated based on typical unit prices in Italy.

\begin{tabular}{ccccc}
\hline Fuel & Unit Price (UP) & $\begin{array}{c}\text { Lower Heating } \\
\text { Value (LHV) }\end{array}$ & Efficiency $\eta \mathrm{G}$ & $\begin{array}{c}\text { Unit Heating Cost } \\
\text { (€/kWhth) }\end{array}$ \\
\hline Oil & $1.280 € / 1$ & $9.6 \mathrm{kWh} / 1$ & $90 \%$ & 0.148 \\
LPG & $1.350 € / 1$ & $7.3 \mathrm{kWh} / 1$ & $90 \%$ & 0.205 \\
Wood logs & $0.115 € / \mathrm{kg}$ & $4 \mathrm{kWh} / \mathrm{kg}$ & $75 \%$ & 0.038 \\
Wood chips & $0.067 € / \mathrm{kg}$ & $3.5 \mathrm{kWh} / \mathrm{kg}$ & $80 \%$ & 0.024 \\
Wood pellets & $0.260 € / \mathrm{kg}$ & $5.2 \mathrm{kWh} / \mathrm{kg}$ & $88 \%$ & 0.057 \\
\hline
\end{tabular}

Costs of heating and DHW production with a heat pump are calculated as the ratio between the unit cost of electricity, which was set to $0.20 € / \mathrm{kWh}_{\mathrm{el}}$ based on recent Eurostat estimates [57], and the SPF, which was set depending on the type (see Table 7). Resulting heating unit costs for different heat pumps are reported in Table 7 and they are by $46 \%$ (air-source heat pump for heating) to $71.9 \%$ (groundwater heat pump) lower than those obtained with oil boilers.

Table 7. Heating unit costs of different kinds of heat pumps.

\begin{tabular}{ccc}
\hline HP Type & SPF & Unit Heating Cost (€/kWhth) \\
\hline Heating ASHP & 2.5 & 0.080 \\
DHW ASHP & 2.8 & 0.071 \\
GCHP & 4.0 & 0.050 \\
GWHP & 4.8 & 0.042 \\
\hline
\end{tabular}

\subsection{Case Studies of Oil Heating Replacement}

Although operational costs are always reduced when replacing oil boilers with heat pumps or fuels other than LPG, the initial investment required is a major barrier to the phase-out of oil heating systems. Two representative case studies have been identified to assess the economic return of such investment in Aosta Valley:

- A detached house equipped with a $30 \mathrm{~kW}$ oil boiler with instantaneous production of DHW, with a heating need of $15 \mathrm{MWh}_{\text {th }} /$ year and a DHW need of $4 \mathrm{MWh}_{\text {th }} /$ year. The heating terminals are 10 high temperature radiators (HTR);

- A block of 50 flats with a centralized oil boiler with a power of $150 \mathrm{~kW}$ and a heating need of $300 \mathrm{MWh}_{\mathrm{th}} /$ year. DHW is produced separately in each flat with a total number of $50 \mathrm{DHW}$ electric boilers (with an efficiency of $75 \%$ as suggested by Ref. [58]), with a total production of $100 \mathrm{MWh}_{\text {th }} /$ year. Each flat has five high-temperature radiators, so the total number of HTR is 250 . 
A few alternatives to oil heaters were considered, based on what reported in Section 2. For the detached house, six technical alternatives were considered:

- An LPG boiler with the same power $(30 \mathrm{~kW})$ and with a tank supplied as loan for use, for which no expense is incurred by the customer;

- A wood log boiler $(10 \mathrm{~kW})$ with a DHW heat pump;

- A wood chips boiler $(10 \mathrm{~kW})$ with a DHW heat pump;

- A wood pellet boiler (10 kW) with a DHW heat pump;

- An air-source heat pump $(10 \mathrm{~kW})$ used for both heating and DHW, with the replacement of the 10 HTRs with low temperature radiators (LTRs);

- A ground-coupled heat pump $(10 \mathrm{~kW})$ used for both heating and DHW, with the replacement of the 10 HTRs with low temperature radiators (LTRs). The GCHP is connected to two borehole heat exchangers (100 $\mathrm{m}$ each), based on a cautious estimation of the shallow geothermal potential based on Ref. [35].

The groundwater heat pump was not considered for the detached house since the operational savings are not worth the bureaucratic burden for its approval and the maintenance operations required. For the block of 50 flats, six solutions were considered for the replacement of the oil boiler:

- A centralized LPG boiler with the same power (150 kW), with a tank supplied as loan for use, and the replacement of the 50 electric boilers with DHW heat pumps;

- A centralized wood chips boiler $(150 \mathrm{~kW})$ with a DHW heat pump for each of the 50 flats;

- A centralized wood pellet boiler $(150 \mathrm{~kW})$ with a DHW heat pump for each of the 50 flats;

- A centralized air-source heat pump (150 kW) used for heating, the replacement of the 50 electric boilers with DHW heat pumps and the installation of 250 LTRs to replace HTRs;

- A centralized ground-coupled heat pump $(150 \mathrm{~kW})$ used for heating and connected to 30 BHEs (100 m each), the replacement of the 50 electric boilers with DHW heat pumps and the installation of 250 LTRs to replace HTRs;

- A centralized groundwater heat pump $(150 \mathrm{~kW})$ used for heating and connected to 2 wells for abstraction and injection, the replacement of the 50 electric boilers with DHW heat pumps and the installation of 250 LTRs to replace HTRs.

The individual costs estimated for components and their installation are reported in Table 8 and are based on a market survey.

The individual electric DHW heaters of the block of flats were replaced in all the intervention hypotheses. Replacing electric water heaters with heat pumps strongly reduces both energy consumption $(-73 \%$ with the SPF $=2.8$ reported in Table 7$)$ and electric load $(-79 \%$, i.e., from $1.2 \mathrm{~kW}$ to $0.25 \mathrm{~kW}$ based on catalogues of [59]). The electric load is an important issue since electric water heaters draw a large share of the available power of a residential electric utility (typically, $3 \mathrm{~kW}$ ) for a few hours per day, thus, limiting further use of electric appliances.

Different wood biomass boilers (logs, chips, and pellets) were coupled with small DHW air source heat pumps to reduce the number of the boiler startups and hence the pollutant emissions.

Wood log boilers based on gasification were not considered for the block of flats, due to a lack of automatic feeding, and therefore an unpractical application to large plants (150 kW).

Regarding heat pumps, the replacement of high-temperature radiators (HTR) with low-temperature ones (LTR), was applied to achieve the SPF values reported in Table 7. 
Table 8. Unit costs estimated for heating solutions hypothesized for the replacement of oil boilers.

\begin{tabular}{cc}
\hline Component/Intervention & Unit Cost (€) \\
\hline DHW ASHP (1 kW) & 2000 \\
30 kW LPG boiler & 3000 \\
150 kW LPG boiler & 10,000 \\
$10 \mathrm{~kW}$ wood log boiler & 10,000 \\
$10 \mathrm{~kW}$ wood chip boiler & 15,000 \\
$10 \mathrm{~kW}$ wood pellet boiler & 15,000 \\
$150 \mathrm{~kW}$ wood chip boiler & 50,000 \\
$150 \mathrm{~kW}$ wood pellet boiler & 50,000 \\
$10 \mathrm{~kW}$ HP (of any type) & 12,000 \\
$150 \mathrm{~kW}$ HP (of any type) & 60,000 \\
BHE 100 m & 6000 \\
well 20 m & 20,000 \\
LTR & 600 \\
\hline
\end{tabular}

\subsection{Estimation of Payback Times}

The economic convenience of the proposed solution was evaluated using a simple payback time (PBT), calculated as the ratio between the installation expense and the sum of the operational savings and the incentives granted. In Italy, the current incentive regime consists of a reimbursement of $65 \%$ of the expenses incurred, with a yearly payment over 10 years [60]. Payback time values without incentives were also calculated, to allow a comparison with other countries, and to consider possible variations in incentive schemes. The PBT values shown in Figure 3 range from about 6-16 years without incentives and from 3 to 8 years with the incentives described above. As expected, wood heating has a quicker return on investment than heat pumps due to low operational costs and to a lower initial investment required. Heat pumps require low-temperature heating terminals (fan coils, radiant panels or LTR) which are rarely present in old buildings, so their installation largely increases the initial investment. However, GWHPs are very competitive for larger dwellings, since they achieve very low operational costs with a reduced additional investment for well drilling.

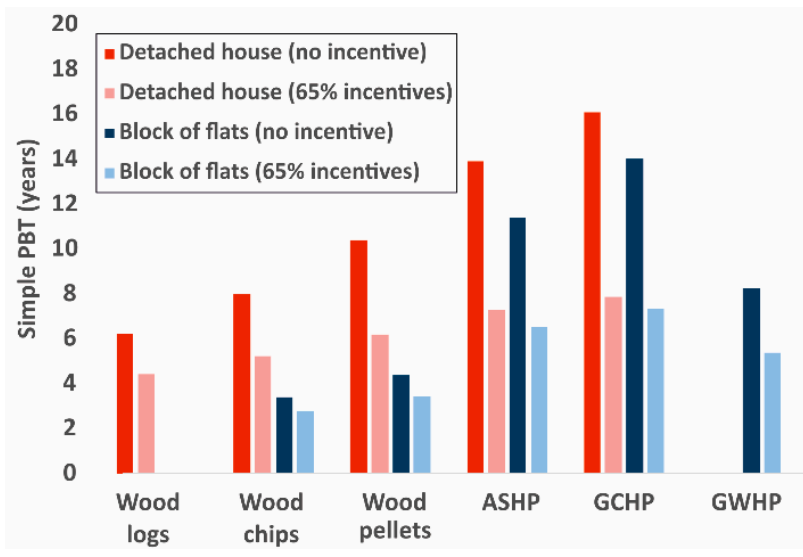

Figure 3. Payback times, calculated without (dark columns) and with incentives (light-colored columns), for different oil heating replacement solutions in a detached house and in a block of flats.

\subsection{Solar Thermal DHW Production System}

The analysis conducted so far did not consider the opportunity of introducing solar thermal panels to produce domestic hot water (DHW). This choice is motivated by the need to consider combinations of techniques which could be applied even in contexts for which solar thermal panels are not performing.

Solar thermal panels could not cover all the DHW yearly demand in Aosta Valley, due to the low winter temperatures. For this reason, thermal panels could be coupled to the heat pump, both 
those dedicated to the DHW production and those which also perform space heating. The economic benefit of solar thermal panels is the avoided electrical consumption on a share of the total DHW production which could be reasonably be estimated as 50\% in Aosta Valley. Table 9 reports the results of the economic feasibility analysis, which was restricted to the detached house since connecting all the 50 flats to a collective solar plant would have been hardly feasible. The payback time proves satisfactory and comparable to that of a wood pellet boiler (see Figure 3). Therefore, installing solar thermal panels would improve the overall payback time of a heat pump heating solution (both air-source and ground-coupled types), which have longer payback times, and would slightly worsen the economic performance of boilers fueled with wood logs or chips, which have shorter payback times.

Table 9. Economic evaluation of installing solar thermal panels in the detached house.

\begin{tabular}{cc}
\hline Parameter & Value \\
\hline Installation cost $(€)$ & $1500 €$ \\
DHW need (MWh th $\left._{\text {year }}\right)$ & 4 \\
DHW produced with solar panels $(\mathrm{MWh}$ th/year) & 2 \\
Saving margin (€/year) & 142.86 \\
Simple payback time (years) & 10.50 \\
Simple payback time, with incentives & 6.24 \\
\hline
\end{tabular}

\subsection{Solar Photovoltaic Plant}

The economic feasibility analysis did not consider the opportunity of installing a photovoltaic (PV) plant. This choice is motivated by the idea of considering the production of heating and DHW only, i.e., the functions for which oil boilers must be replaced. Since installing a photovoltaic plant would provide a benefit also for electrical uses other than heat pumps, a separate analysis was performed considering both the detached house and the block of flats. In the former, the PV plant is mostly dedicated to self-consumption, with a minor share to be sold on the grid at a relatively low price. In the case of the block of flats, the PV plant would cover part of the electricity need of the centralized heat pump during the heating season while, in the other part of the year, almost all production would be sold to the grid. In this case, however, the analysis considered the feed-in incentive of which will be granted by the forthcoming Italian incentive scheme [61]. Table 10 reports the input values and the results of the economic analysis performed. It turns out that, for a detached house, a PV plant has a payback time that is similar to that of heat pump solutions, while shorter payback times would be achieved for a block of flats due to the economies of scale with a larger power installed.

Table 10. Economic evaluation of installing a PV plant in a detached house and in a block of flats.

\begin{tabular}{ccc}
\hline Parameter & Detached House & Block of Flats \\
\hline Installed power $(\mathrm{kW})$ & 3 & 50 \\
Installation cost $(€)$ & 8000 & 60,000 \\
Productivity $(\mathrm{kWh} / \mathrm{kW} / \mathrm{kear})$ & 1000 & 1000 \\
Production $(\mathrm{kWh} / \mathrm{el} /$ year) & 3000 & 50,000 \\
Self-consumption share & $70 \%$ & $30 \%$ \\
Share delivered to the grid & $30 \%$ & $70 \%$ \\
Electrical tariff from the grid $\left(€ / \mathrm{kWh}_{\mathrm{el}}\right)$ & 0.200 & 0.200 \\
Electrical tariff to the grid $(€ / \mathrm{kWh}$ el & 0.040 & 0.105 \\
Yearly revenue $(€ / \mathrm{kWh} /)$ & 0.152 & 0.134 \\
Yearly revenue $(€ /$ year) & 456 & 6675 \\
Simple payback time $($ years $)$ & 17.54 & 8.99 \\
Simple payback time, with incentives (years) & 9.35 & 6.20 \\
\hline
\end{tabular}




\section{Discussion}

The technical, environmental and economic analyses reported in the previous chapter provide an information basis to support the choice of the most suitable technique to replace oil heating.

The evaluation of technical issues depends on the utilization context of the heating system since choice factors have different weights depending on the target user. For example, a number of recent studies on heat pump uptake highlighted that residential users are keener on choosing the heating technique based on perceived reliability and ease of installation rather than financial criteria $[62,63]$ which, on the other hand, are the most important driver for heating choices in the commercial and industrial sectors [13]. Literature in this field agrees on the fact that large installation costs are a strong drawback for heating technologies, even in the case of substantial reduction of the operational costs and reasonable payback times $[13,62,63]$.

Heat pumps could be the most technically suitable heating technology for most of users since they combine no need for fuel refill nor storage, no attendance, and the least safety issue; however, the difficulty to integrate them in existing buildings (i.e., fitting them into the available space and coupling them with high temperature radiators, which are still the most used terminals) is a major obstacle to their diffusion, along with noise issues for the air-source type. On the other hand, fuel refill and storage are the main drawdowns for biomass boilers, along with the time-consuming management of the system (i.e., maintenance, boiler refill etc.).

The economic evaluation of technical solutions highlights that the initial investment may be the strongest barrier for the diffusion of both wood biomass boilers and heat pumps. Payback times are made attractive ( 3 to 8 years) by the Italian governmental incentives for energy refurbishment. These incentives are also granted to fossil fuel boilers if they meet certain efficiency criteria [60]: removing fossil fuel boilers from incentive schemes would further encourage the phase-out of oil at the end of the technical lifetime of the boiler.

Wood biomass boilers have lower costs of installation and shorter payback times compared to heat pumps, and this is a particularly strong driver for the choice of the heating technique.

Replacing oil boilers has multiple environmental benefits, namely i) the removal of the threat to groundwater resources represented by USTs, ii) the reduction of greenhouse gas emissions and iii) the reduction of air pollutant emissions. With the current energy mix adopted in Italy, wood biomass still is less carbon-intensive than heat pumps, although this advantage is likely to further decrease in the future due to the progressive increase of the use of renewables to produce electricity. On the other hand, as highlighted previously, boilers using wood biomass (especially wood logs) have very large particulate, CO and VOC emissions. This is a particularly important issue in Aosta Valley, which has unfavorable conditions for air quality due to the confinement effect of mountain chains. The latest yearly report on air quality by ARPA Valle d'Aosta (2018, [64]) shows yearly average PM10 of about $20 \mu \mathrm{g} / \mathrm{m}^{3}$ in the monitored sites in the bottom valley (Aosta and Donnas): while this value is well below the legislative threshold of $40 \mu \mathrm{g} / \mathrm{m}^{3}$, wood biomass heating is responsible for more than $70 \%$ of these emissions. Also, wood burning has a major contribution to $\mathrm{PAH}, \mathrm{SO}_{\mathrm{x}}$ and $\mathrm{CO}$ concentrations. A further increase of the use of wood biomass should therefore be accompanied by strong policy actions to upgrade existing boilers and reduce impacts on the air quality in this region.

Considering technical issues, economic viability, GHG and air pollutant emissions, heat pumps prove to be the most suitable solution for replacing oil heating systems in Aosta Valley. Among them, air-source heat pumps have lower installation costs, but their efficiency could greatly be impaired by icing, which may occur when the evaporator temperature is below $0{ }^{\circ} \mathrm{C}$ and the dew point of air [30]. In addition, very low air temperatures reached during winter could make the operation of air-source heat pump critical due to the reduction of the delivered power and of the SPF. These two factors should be taken into great consideration especially in the Aosta Valley, since oil boilers to be replaced are often located at high elevations with a cold climate. Ground-source heat pumps are not affected by seasonal variations of the air temperature, with a consequent efficiency gain over air-source heat pumps. In addition, most of the territory of the Aosta Valley has a high potential for heat exchange with BHEs [35] 
both in the bottom valley, where the alluvial sediments have a medium-high thermal conductivity and medium-high temperature, and at higher elevations, where the high thermal conductivity of rocks compensates the negative effect of lower subsurface temperatures [35,36]. The Aosta Valley already has 43 BHE systems installed [35], among which a plant operating at $2400 \mathrm{~m}$ a.s.l. in Cervinia [65] which is, to our knowledge, the highest in the world for a GSHP. Also, a few alluvial plains are present (Aosta, Pont-Saint-Martin, Issogne-Verres), where 24 GWHPs have already been installed [35]. In particular, the Aosta plain has a great potential for development of open-loop systems $[36,66,67]$.

\section{Conclusions}

Although declining, oil heating systems are still quite commonly used, especially in scarcely populated areas not reached by gas pipelines. Most of oil heating systems use USTs, which represent one of the most used potential groundwater contamination sources. This issue has been addressed since the early 80's in the USA and, more recently, in Europe. In Italy, a recent study conducted on the Aosta Valley region revealed that 68 (suspect) UST leakage episodes have occurred between 1999 and 2018, of which ten were remediated. A relevant share of gas station tanks had leakage issues, while relatively few spills were found from heating oil tanks, which are much more numerous. This could be attributed to the absence of any compulsory monitoring on heating USTs, contrary to gas stations, and highlights the need to both implement periodic controls on all hydrocarbon storage tanks and to proceed to a rapid phase-out of oil heating, the impact of which is not limited to soil and groundwater. Oil is among the most carbon-intensive fuels and has a noticeable impact on air quality, especially PM10 and $\mathrm{SO}_{\mathrm{x}}$ emissions.

The techno-economic feasibility of alternatives to oil heating was therefore examined, with reference to Italian unit costs of energy and incentive schemes. Wood logs and chips boilers are the cheapest and least carbon-intensive alternatives, but their impact on air quality is to be considered critical, and their need for large storage spaces could be a strong limiting factor for large buildings plants. On the other hand, heat pumps are more expensive and have longer payback times compared to wood fuels, but they produce no emissions on site, and present dramatically reduced GHG and pollutant emissions on a global scale; in addition, they do not require fuel storage. Payback times for the replacing of oil boilers range between 6 and 16 years without considering incentives, and from about 3-8 years considering Italian current incentives for residential buildings. Including solar thermal panels to integrate the DHW production of the heat pump, as well as a photovoltaic system which could partially cover the electric demand of the heat pump, has a similar payback time (6-9 years considering incentives).

These figures confirm the economic feasibility of a rapid phase-out of oil heating systems in Aosta Valley and in other Italian regions.

Author Contributions: Conceptualization, A.C., P.C.; methodology, A.C., P.C.; investigation, A.C., P.C., F.S.; data curation, A.C., P.C., F.S.; writing — original draft preparation, A.C.; writing - review and editing, P.C., R.S.; supervision, R.S.; project administration, A.C., P.C.; funding acquisition, A.C., P.C., R.S.

Funding: This research work was conducted within the GRETA project, grant ASP172, and supported by the European Regional Development Fund (ERDF) through the Alpine Space program.

Acknowledgments: The authors gratefully acknowledge the valuable contributions of Valentina Quaranta, who assisted in the proofreading and language editing of the manuscript, and of Eugenio Andorno (Geonovis) for his help in the quantification of installation expenses of HVAC components in the economic analysis performed.

Conflicts of Interest: The authors declare no conflict of interest. The funders had no role in the design of the study; in the collection, analyses, or interpretation of data; in the writing of the manuscript, or in the decision to publish the results.

\section{References}

1. Ürge-Vorsatz, D.; Cabeza, L.F.; Serrano, S.; Barreneche, C.; Petrichenko, K. Heating and cooling energy trends and drivers in buildings. Renew. Sustain. Energy Rev. 2015, 41, 85-98. [CrossRef] 
2. Fleiter, T.; Elsland, R.; Rehfeldt, M.; Steinbach, J.; Reiter, U.; Catenazzi, G.; Jakob, M.; Rutten, C.; Harmsen, R.; Dittmann, F.; et al. Profile of Heating and Cooling Demand in 2015. Heat Roadmap Europe Deliverable 3.1. Available online: http://bit.ly/2Hy4xFI (accessed on 31 March 2019).

3. EIA Weekly U.S. Weekly No. 2 Heating Oil Residential Price. Available online: http://bit.ly/2W9Ztk5 (accessed on 20 February 2019).

4. Dowd, R.M. Leaking underground storage tanks. Environ. Sci. Technol. 1984, 18, 309A. [CrossRef]

5. Ram, N.M.; Scott, J.; Szymaszek, K.; Swanson, D. Developing life-cycle environmental response costs for leaking underground storage systems at service station sites. Remediat. J. 2014, 24, 65-77. [CrossRef]

6. Sweet, F.; Kauffman, M.; Pellerin, T.; Espy, D.; Mills, M. An estimate of the national cost for remediation of MTBE releases from existing leaking underground storage tank sites. Proc. Ann. Int. Conf. Soils Sediments Water Energy 2010, 11, 12.

7. US EPA Underground Storage Tanks (USTs). Available online: https://www.epa.gov/ust (accessed on 13 September 2018).

8. Casasso, A.; Piga, B.; Sethi, R.; Prestor, J.; Pestotnik, S.; Bottig, M.; Goetzl, G.; Zambelli, P.; D'Alonzo, V.; Vaccaro, R.; et al. The GRETA project: The contribution of near-surface geothermal energy for the energetic self-sufficiency of Alpine regions. Acque Sotter. Ital. J. Groundw. 2017, 6, 1-12. [CrossRef]

9. Casasso, A.; Capodaglio, P.; Simonetto, F.; Sethi, R. Economic and Environmental Benefits of Phase-Out of Oil Heating Systems. Available online: https://bit.ly/2MlNjAZ (accessed on 31 March 2019).

10. Regione Valle d'Aosta, ARPA Valle d'Aosta. Linee Guida Serbatoi Interrati-Regione Autonoma Valle d'Aosta (Guidelines on Underground Storage Tanks). Available online: https://bit.ly/2LvV8Ca (accessed on 31 March 2019).

11. Hast, A.; Ekholm, T.; Syri, S. What is needed to phase out residential oil heating in Finnish single-family houses? Sustain. Cities Soc. 2016, 22, 49-62. [CrossRef]

12. Karytsas, S. An empirical analysis on awareness and intention adoption of residential ground source heat pump systems in Greece. Energy Policy 2018, 123, 167-179. [CrossRef]

13. Chinese, D.; Nardin, G.; Saro, O. Multi-criteria analysis for the selection of space heating systems in an industrial building. Energy 2011, 36, 556-565. [CrossRef]

14. Kheirbek, I.; Haney, J.; Douglas, S.; Ito, K.; Caputo, S.; Matte, T. The public health benefits of reducing fine particulate matter through conversion to cleaner heating fuels in New York City. Environ. Sci. Technol. 2014, 48, 13573-13582. [CrossRef]

15. Sarigiannis, D.A.; Karakitsios, S.P.; Kermenidou, M.V. Health impact and monetary cost of exposure to particulate matter emitted from biomass burning in large cities. Sci. Total Environ. 2015, 524-525, 319-330. [CrossRef]

16. Mercalli, L.; Cat Berro, D. Atlante Climatico Della Valle d'Aosta/Coord. Luca Mercalli; Societá Meteorologica Subalpina: Torino, Italy, 2003.

17. Eurostat Energy Statistics-Cooling and Heating Degree Days. Available online: https://ec.europa.eu/ eurostat/cache/metadata/en/nrg_chdd_esms.htm (accessed on 26 June 2019).

18. EU Science Hub, JRC. Photovoltaic Geographical Information System (PVGIS). Geographical Assessment of Solar Resource and Performance of Photovoltaic Technology. Available online: http://re.jrc.ec.europa.eu/pvgis/ (accessed on 26 June 2019).

19. ISTAT: I Consumi Energetici delle Famiglie (Energetic Consumption of Italian Families, Divided by Region). Available online: https://www.istat.it/it/archivio/142173 (accessed on 17 September 2018).

20. Unione Petrolifera Statistiche Economiche Energetiche e Petrolifere 2018 (Italian Oil Sector Statistics 2018). Available online: http://bit.ly/2JMMEpq (accessed on 23 May 2019).

21. MISE Ambiti Territoriali del Settore della Distribuzione del Gas Naturale. Available online: http://bit.ly/ 2VAJLtY (accessed on 11 March 2018).

22. COA Finaosta; Regione Valle d'Aosta Catasto Impianti Termici della Regione Valle d'Aosta (Cadastre of Heating Systems of Aosta Valley). Available online: http://bit.ly/2WeNPW2 (accessed on 11 December 2018).

23. Bioenergy Europe Statistical Report 2018; Bioenergy Europe: Brussels, Belgium, 2019.

24. Boait, P.J.; Fan, D.; Stafford, A. Performance and control of domestic ground-source heat pumps in retrofit installations. Energy Build. 2011, 43, 1968-1976. [CrossRef]

25. Huchtemann, K.; Müller, D. Simulation study on supply temperature optimization in domestic heat pump systems. Build. Environ. 2013, 59, 327-335. [CrossRef] 
26. EHPA European Heat Pump Market and Statistic Report 2017 \& Stats Tool. Available online: https: //www.ehpa.org/market-data/2017/ (accessed on 14 December 2018).

27. Caird, S.; Roy, R.; Potter, S. Domestic heat pumps in the UK: User behaviour, satisfaction and performance. Energy Effic. 2012, 5, 283-301. [CrossRef]

28. Omlin, S.; Bauer, G.; Brink, M. Effects of noise from non-traffic-related ambient sources on sleep: Review of the literature of 1990-2010. Noise Health 2011, 13, 299-309. [CrossRef] [PubMed]

29. Hundy, G.F. Refrigeration, Air Conditioning and Heat Pumps; Elsevier: Amsterdam, The Netherlands, 2016; ISBN 0-08-100666-7.

30. Vocale, P.; Morini, G.L.; Spiga, M. Influence of outdoor air conditions on the air source heat pumps performance. Energy Procedia 2014, 45, 653-662. [CrossRef]

31. Casasso, A.; Sethi, R. Technology and potentiality of geothermal heat pumps. Geoingegneria Ambientale e Mineraria 2013, 138, 13-22.

32. Sarbu, I.; Sebarchievici, C. General review of ground-source heat pump systems for heating and cooling of buildings. Energy Build. 2014, 70, 441-454. [CrossRef]

33. Staffell, I.; Brett, D.; Brandon, N.; Hawkes, A. A review of domestic heat pumps. Energy Environ. Sci. 2012, 5, 9291-9306. [CrossRef]

34. Repubblica Italiana. D.Lgs. 152/2006-Norme in Materia Ambientale (Legislative Decree no. 152/2006. Norms on the Environment). 2006. Available online: https://www.camera.it/parlam/leggi/deleghe/06152dl.htm (accessed on 27 March 2019).

35. Casasso, A.; Della Valentina, S.; Di Feo, A.F.; Capodaglio, P.; Cavorsin, R.; Guglielminotti, R.; Sethi, R. Ground source heat pumps in Aosta Valley (NW Italy): Assessment of existing systems and planning tools for future installations. Rendiconti Online Societa Geologica Italiana 2018, 46, 59-66. [CrossRef]

36. EURAC. Web GIS Maps of the Geothermal Potential in Valle d'Aosta (Italy). Available online: http: //greta.eurac.edu/maps/177/embed (accessed on 7 February 2019).

37. IINAS. GEMIS—Global Emissions Model for integrated Systems. Available online: http://iinas.org/gemis.html (accessed on 25 September 2018).

38. Klein, D.; Wolf, C.; Schulz, C.; Weber-Blaschke, G. Environmental impacts of various biomass supply chains for the provision of raw wood in Bavaria, Germany, with focus on climate change. Sci. Total Environ. 2016, 539, 45-60. [CrossRef]

39. Sjølie, H.K.; Solberg, B. Greenhouse gas emission impacts of use of Norwegian wood pellets: A sensitivity analysis. Environ. Sci. Policy 2011, 14, 1028-1040. [CrossRef]

40. Thrän, D.; Peetz, D.; Schaubach, K. Global Wood Pellet Industry and Trade Study 2017. In IEA Bioenergy Task 40; IEA: Paris, France, 2018; p. 243.

41. Bechis, S.; Marangon, F. Analisi Delle Emissioni di CO2 Nelle Diverse Fonti Energetiche (Analysis of CO2 Emissions of Energy Sources. Available online: https://goo.gl/HsNji8 (accessed on 27 September 2018).

42. Francescato, V. Caldaie e Impianti a Biomasse Legnose: Tecnologie, Costi e Rendimenti (Wood Biomass Boilers: Technologies, Costs, and Energy Efficiencies). Available online: https://goo.g1/r2RWhq (accessed on 27 September 2018).

43. Pachauri, R.K.; Mayer, L. Climate Change 2014: Synthesis Report; Intergovernmental Panel on Climate Change: Geneva, Switzerland, 2015; ISBN 978-92-9169-143-2.

44. Herich, H.; Gianini, M.F.D.; Piot, C.; Močnik, G.; Jaffrezo, J.-L.; Besombes, J.-L.; Prévôt, A.S.H.; Hueglin, C. Overview of the impact of wood burning emissions on carbonaceous aerosols and PM in large parts of the Alpine region. Atmos. Environ. 2014, 89, 64-75. [CrossRef]

45. Pietrogrande, M.C.; Bacco, D.; Ferrari, S.; Kaipainen, J.; Ricciardelli, I.; Riekkola, M.L.; Trentini, A.; Visentin, M. Characterization of atmospheric aerosols in the Po valley during the supersito campaigns—Part 3: Contribution of wood combustion to wintertime atmospheric aerosols in Emilia Romagna region (Northern Italy). Atmos. Environ. 2015, 122, 291-305. [CrossRef]

46. Szidat, S.; Prévôt, A.S.H.; Sandradewi, J.; Alfarra, M.R.; Synal, H.-A.; Wacker, L.; Baltensperger, U. Dominant impact of residential wood burning on particulate matter in Alpine valleys during winter. Geophys. Res. Lett. 2007, 34. [CrossRef]

47. Nussbaumer, T. Aerosols from Biomass Combustion; Technical Report on Behalf of the IEA Bioenergy Task 32; IEA: Paris, France, 2017; pp. 1-32. 
48. Toscano, G.; Duca, D.; Amato, A.; Pizzi, A. Emission from realistic utilization of wood pellet stove. Energy 2014, 68, 644-650. [CrossRef]

49. Win, K.M.; Persson, T.; Bales, C. Particles and gaseous emissions from realistic operation of residential wood pellet heating systems. Atmos. Environ. 2012, 59, 320-327. [CrossRef]

50. Wang, K.; Satyro, M.A.; Taylor, R.; Hopke, P.K. Thermal energy storage tank sizing for biomass boiler heating systems using process dynamic simulation. Energy Build. 2018, 175, 199-207. [CrossRef]

51. SINANET Fattori di Emissione per la Produzione ed il Consumo di Energia Elettrica in Italia (Emission Factors for the Production and the Consumption of Electricity in Italy). Available online: http://bit.ly/2VNne2b (accessed on 28 September 2018).

52. Saner, D.; Juraske, R.; Kübert, M.; Blum, P.; Hellweg, S.; Bayer, P. Is it only CO2 that matters? A life cycle perspective on shallow geothermal systems. Renew. Sustain. Energy Rev. 2010, 14, 1798-1813. [CrossRef]

53. European Commission EU Legislation to Control F-Gases. Available online: https://ec.europa.eu/clima/ policies/f-gas/legislation_en (accessed on 27 September 2018).

54. Rivoire, M.; Casasso, A.; Piga, B.; Sethi, R. Assessment of energetic, economic and environmental performance of ground-coupled heat pumps. Energies 2018, 11, 1941. [CrossRef]

55. Bayer, P.; Saner, D.; Bolay, S.; Rybach, L.; Blum, P. Greenhouse gas emission savings of ground source heat pump systems in Europe: A review. Renew. Sustain. Energy Rev. 2012, 16, 1256-1267. [CrossRef]

56. MISE. Strategia Energetica Nazionale (SEN) 2017 (Italian National Energy Strategy 2017). Available online: http://bit.ly/30t25cj (accessed on 3 November 2018).

57. Eurostat Electricity Price Statistics. Available online: http://bit.ly/2LUlFen (accessed on 14 December 2018).

58. UNI/TS. UNI TS 11300-2: Prestazioni Energetiche Degli Edifici, Parte 2. (Energy Performance of Buildings, Part 2). Available online: https://bit.ly/2FL65Mn (accessed on 26 June 2019).

59. Ariston. Ariston Thermo-Water Heating. Available online: http://www.ariston.com/ww/ (accessed on 3 November 2018).

60. Agenzia delle Entrate Guida Agevolazioni Risparmio Energetico (Guide to Incentives for Energy Saving). Available online: http://bit.ly/2Q7B0GG (accessed on 18 March 2019).

61. MISE. Schema di Decreto Ministeriale Sugli Incentivi alle Fonti Rinnovabili Elettriche "FER 1" (Draft of Incentive Scheme for Electricity Produced from Renewable Energy Sources). Available online: https: //www.casaportale.com/public/uploads/17015-pdf5.pdf (accessed on 26 June 2019).

62. Owen, A.; Mitchell, G.; Unsworth, R. Reducing carbon, tackling fuel poverty: Adoption and performance of air-source heat pumps in East Yorkshire, UK. Local Environ. 2013, 18, 817-833. [CrossRef]

63. Snape, J.R.; Boait, P.J.; Rylatt, R.M. Will domestic consumers take up the renewable heat incentive? An analysis of the barriers to heat pump adoption using agent-based modelling. Energy Policy 2015, 85, 32-38. [CrossRef]

64. ARPA. Valle d'Aosta Qualità dell'aria in Valle d'Aosta. Aggiornamento al 31 dicembre 2017 (Air quality in Aosta Valley. Update as of December 31st, 2017). Available online: https://bit.ly/2vbM7oD (accessed on 29 May 2019).

65. Fabrizio, E.; Ferrara, M.; Urone, G.; Corgnati, S.P.; Pronsati, S.; Filippi, M. Performance assessment of a solar assisted ground source heat pump in a mountain site. Energy Procedia 2015, 78, 2286-2291. [CrossRef]

66. Casasso, A.; Della Valentina, S.; Bucci, A.; Tiraferri, A.; Tosco, T.; Sethi, R.; Prestor, J.; Pestotnik, S.; Rajver, D.; Capodaglio, P.; et al. Local-Scale Maps of the NSGE Potential in the Case Study Areas-GRETA Project Deliverable 4.2.1; TUM: Munich, Germany, 2018.

67. Böttcher, F.; Casasso, A.; Götzl, G.; Zosseder, K. TAP-Thermal aquifer potential: A quantitative method to assess the spatial potential for the thermal use of groundwater. Renew. Energy 2019, 142, 85-95. [CrossRef]

(C) 2019 by the authors. Licensee MDPI, Basel, Switzerland. This article is an open access article distributed under the terms and conditions of the Creative Commons Attribution (CC BY) license (http://creativecommons.org/licenses/by/4.0/). 